\title{
Evaluation of the Injana claystone from Central Iraq for the brick industry
}

\author{
Salih M. Awadh,Ali M. Awad* \\ Dept. of Geology, College of Science, University of Baghdad, Iraq \\ *Corresponding author: alimutlag2200@yahoo.com
}

\begin{abstract}
This study aims to suggest an alternative to the use of quality agricultural soil in the brick industry (Iraq). The Late Miocene claystone bed in the Injana Formation in central Iraq was targeted through the study of 18 exposed sections that were sampled by using the trench sampling method. The claystones are characterized by quartz (36.4\%) followed by calcite (32.8\%), quartz (36.4\%) feldspar (2.6\%), gypsum (1.3\%) and dolomite (0.7\%), kaolinite (10.5\%), illite (7.7\%), chlorite $(6.7 \%)$, palygorskite $(6.0 \%)$ and montmorillonite $(0.7 \%)$. New thermal mineral phases were formed at $950^{\circ} \mathrm{C}$, including diopside $(62.9 \%)$, quartz (18.4\%), wollastonite $(8.28 \%)$, akermanite (7.6\%), Anorthite (6.25\%), Nosean (4.9\%), gehlenite $(3.75 \%)$ and Lazurite $(3.15 \%)$. The raw material's engineering tests showed that the Atterberg index for the plasticity varies from low to high, low volumetric and linear shrinkage during drying and firing with a temperature at $950^{\circ} \mathrm{C}$. The raw material produced bricks with $155 \mathrm{~kg} / \mathrm{cm}^{2}$ uniaxial compressive strength, $23.2 \%$ water absorption, and zero to low efflorescence. The results show the potential use of the Late Miocene clays of the Injana Formation to replace the existing agricultural grade muds presently being manufactured within the A and B category based on the Iraqi standard specification No.25 in 1993.
\end{abstract}

Keywords: Bricks; compressive strength; geotechnical evaluation; Injana Formation claystone; Atterberg limit.

\section{Introduction}

The original raw material for brick production in ancient times was clay soil, and today there is a paucity of mineral reserves of high-quality claystone sources to satisfy the markets (Š́l, 2019). Currently, bricks are made in Iraq from recent clay of the floodplains, which is fertile soil that can be invested solely for agriculture. The continuation of such activity will eventually lead to a reduction in agricultural output due to the over-exploitation of the river basins in Iraq. The rapid population growth led to increased bricks for consumption, resulting in depletion of the soil from agricultural lands. Alternatives exist. The large deposits of Injana clays provide a new potential source that will lead to better conservative actions for the alluvium clays in Iraq's river basins. The Injana Formation (Late Miocene) was targeted due to its extensive reserve of clay. In the area of interest, the Injana formation is very well exposed along a region called the Tar located in the Karbala-Najaf Plateau. The previous studies were done by Merza \& Mohyaldin, 2005; Maala et al., 2007; Ismail \& Omar, 2014, mentioned that the Late Miocene 
claystones in $\mathrm{N}$ Iraq conform to the parameter specifications regarding the raw material of brick manufacturing. This paper is going to: 1) Assess the mineralogical, chemical, and physical properties of the Late Miocene claystone known as the Injana Formation as raw material for the bricks production, 2) Manufacture of bricks using protocols for lab procedures, and 3) Evaluation of the quality of the produced bricks.

\section{Study area and geological setting}

The study area is exposed on two cliffs known locally: Tar Al-Najaf and Tar Al-Sayyed, situated in Iraq's central part. The area is characterized by vertical cliffs which trend NE-SW and NW-SE, respectively (Figure 1). The exposed rocks in the study area are Injana Formation, Dibdibba Formation, and adjacent Quaternary sediments (Hassan, 2007). The Injana Formation (Late Miocene) is one of the most widespread in central, eastern, and northern Iraq (Buday, 1980), with thickness varies from 9 to $27 \mathrm{~m}$ in the Najaf-Karbala plateau (Dawood, 2000). This formation is divided into two units, the upper cave-forming claystone unit and the lower clastic unit (Awadh \& Aboud, 2013). The section TN3 is displayed below, together with an outcrop stratigraphy in Figure 2.

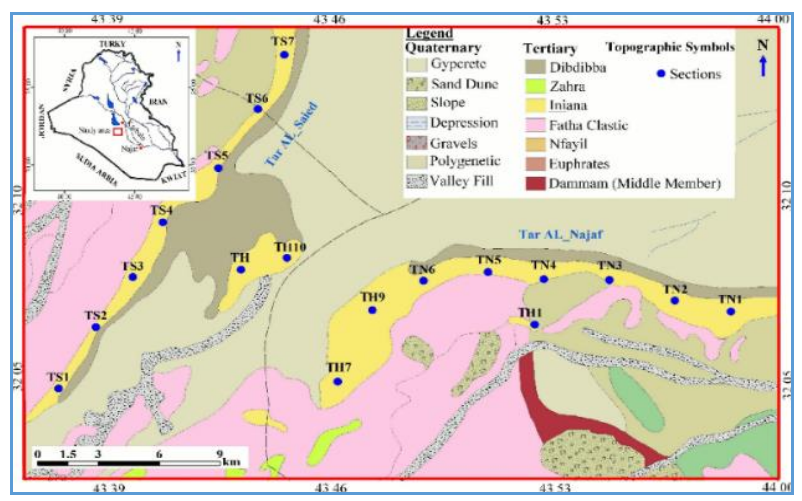

Fig. 1. Geological map shows sections and sampling sites.

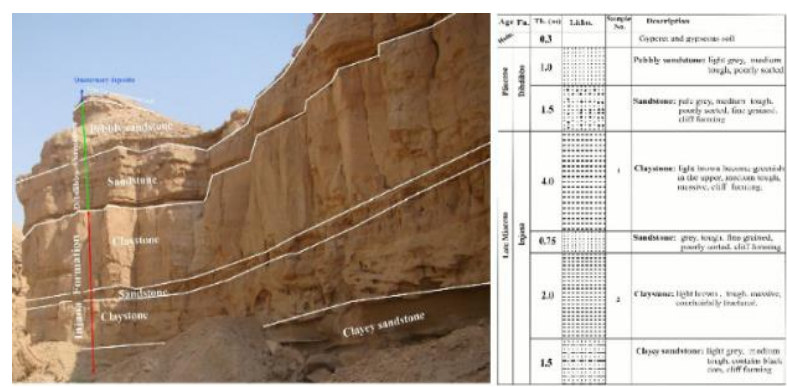

Fig. 2. Stratigraphic column and photo showing section TN3in the study area.

\section{Sampling and methodology}

\subsection{Field and laboratory procedures}

Eighteen stratigraphic sections of Injana exposed rocks were described, from which a total of 33 samples of claystone were collected along the western side of Karbala-Najaf Plateau, locally named Tar Al-Sayyed, Tar AlNajaf, and many adjacent small hills for the chemical analysis. Twelve Samples (TS1-1, TS2-1, TS3-1, TS4-1, TS5-1, TS6-1, TS7-1, TN2-2, TN3-2, TN5-2, TN6-1, and TH7- 1) were selected for the physical tests. The physical tests (grain size analysis, liquid limit, plastic limit, compressive strength (CS) test, efflorescence (Ef) test, water absorption (WA) test, and combustion processes) were conducted in the laboratories of the General Company for Construction Industries in Baghdad. Mineralogical investigation using Xray diffraction (XRD) for seven specimens (oriented and non-oriented) using a Bruker Xray device, type $\mathrm{D} 2$ phaser. The $2 \Theta$ scan of the bulk samples ranged from $5-60^{\circ}$ and between $4-20^{\circ}$ for the oriented samples. The combustion process on samples was conducted at $950{ }^{\circ} \mathrm{C}$ using a Japanese model known as LAC furnace. Twelve samples of claystone were subjected to several heating stages, which were elevated gradually to $950{ }^{\circ} \mathrm{C}$ using 5 minutes' intervals up to a maximum of 120 minutes (Duggal, 2008).

The XRD test was carried out in the Iraqi Germany Laboratory, University of Baghdad. 
All samples were analyzed for $\mathrm{SiO}_{2}, \mathrm{Al}_{2} \mathrm{O}_{3}$, $\mathrm{Fe}_{2} \mathrm{O}_{3}, \mathrm{CaO}, \mathrm{MgO}, \mathrm{K}_{2} \mathrm{O}, \mathrm{Na}_{2} \mathrm{O}, \mathrm{TiO}_{2}, \mathrm{MnO}$, $\mathrm{LOI}, \mathrm{SO}_{3}$, and $\mathrm{Cl}$ by using $\mathrm{X}$-ray fluorescence (XRF) at the ALS laboratory group in Spain using the code number ME-XRF26, and reference materials GIOP-102, NCSDC79001, SARM-5, and SY-4.

\subsection{Geotechnical properties}

The geotechnical properties of claystone were obtained through several laboratory tests includes:

\subsubsection{Grain size analyses}

Wet sieve analysis of claystone was performed by washing the samples. This procedure is capable of separating the fines from the larger grain sizes, especially those that cannot pass through a sieve of 200 mesh (less than 75 microns). Hydrometer analyses were carried out on both silt and clay according to American Standard Test Method D422-63 (2007) ASTM D422-63 (2007).

\subsubsection{Atterberg limit}

Two parameters were tested in order to understand the Atterberg limit. These are the liquid limit and plastic limit. The liquid limit of claystone is the moisture content, expressed as a percentage of the oven-dried claystone's weight, at the boundary between the liquid and plastic states of consistency (Grim, 1962). Water content values can be read easily from the $\mathrm{x}$-axis against 25 blows on the y-axis. A liquid limit test was performed by a Casagrande device (Casagrande, 1947). It is determined according to ASTM for liquid limit, plastic limit, and plasticity index (2005). The plastic limit is the moisture content at which claystone begins to behave as a plastic material, at which water limit (plastic limit), the claystone will crumble when rolled into threads of $3.2 \mathrm{~mm}(1 / 8 \mathrm{in})$ in diameter. This test can be done via rolling the spherical piece of claystone on a glassy plate (Ali et al., 1990). According to ASTM for liquid limit, plastic limit, and plasticity index (2005), the plastic limit was carried out.

\subsubsection{Water absorption test}

This test is used to determine the soil's moisture content as a percentage of its dry weight. The samples are dried in an oven for a specified time at a temperature of $105{ }^{\circ} \mathrm{C}$ and, the bricks were immersed in water for 24 hours and then dried. The difference in weight between the wet and dried brick represents the WA. The WA test was conducted to determine the physical properties that influence the building materials (Shamiah et al., 2018). WA is determined by using Iraqi standard specification No.25, 1993, (ISS No. 25 (1993), which defined the range 22 to $28 \% \mathrm{WA}$ is accepted.

\subsubsection{Efflorescence test}

This test can be summarized by placing one end of the brick in a dish containing distilled water with a shallow level. The water should fill a dish so that the bricks are immersed in a depth of up to $2.5 \mathrm{~cm}$. Since the water is completely absorbed and the brick appears to be dry, a similar amount of water is placed in the dish and allowed to evaporate for seven days. After this process, the effect of brick is examined through Ef (Table 1). The uniaxial compression strength is the maximum axial pressure that a cubic sample of claystone brick can withstand before failure (Topolinski, 2019). When the surface of the bricks is dried, each brick is tested for CS individually. The test brick is compressed between the plates of a compression-testing machine. The uniaxial compression strength was carried out using a 500 kilo Newton (K.N) C70 - Matest mechanical press, with the Cyber-Plus evolution touch-screen control unit. This test was conducted in the laboratories of the General Company for Construction Industries. 
Table 1. Iraqi standard specification number 25,1993 , for clay brick manufacturing.

\begin{tabular}{||l|c|c|c|c||}
\hline \multirow{4}{*}{ Class } & \multirow{2}{*}{$\begin{array}{c}\text { Maximum } \\
\text { absorption } \\
(\%)\end{array}$} & \multicolumn{2}{|c||}{$\begin{array}{c}\text { Minimum compressive } \\
\text { strength }\end{array}$} & \multirow{2}{*}{ Efflorescence } \\
\cline { 3 - 4 } & $\mathbf{1}$ brick & $\mathbf{1}$ brick & $\mathbf{1}$ brick & \\
\cline { 2 - 4 } & & & & \\
\hline A & 22 & 160 & 16 & Low \\
B & 26 & 110 & 11 & Medium \\
C & 28 & 70 & 7 & High \\
\hline
\end{tabular}

3.2.5. Compressive strength test

\subsubsection{Molding}

Twelve samples were molded using the extrusion method. The claystone samples' extrusion process was completed at the central laboratories in Iraq Geological Survey (GEOSURV), Baghdad, Iraq.

\section{Results and discussion}

The geotechnical properties of claystone have been tested and evaluated for suitability in the brick industry as follows:

\section{1. Chemical characteristics of claystone}

The claystone beds in the Injana Formation are presented in Table 2. They composed of $\mathrm{SiO}_{2}$ (40.9\%), $\mathrm{Al}_{2} \mathrm{O}_{3}(9.1 \%), \mathrm{Fe}_{2} \mathrm{O}_{3}(5.6 \%), \mathrm{CaO}$ (17.1\%), $\mathrm{MgO}(5.2 \%), \mathrm{K}_{2} \mathrm{O}(1.6 \%), \mathrm{Na}_{2} \mathrm{O}$ (1.7\%), $\mathrm{TiO}_{2}(0.77 \%), \mathrm{MnO}(0.09 \%)$, LOI (16.1\%), $\mathrm{Cl}(0.7 \%)$, and $\mathrm{SO}_{3}(0.6 \%)$. The average content of elements was compared to the results of Al-Qazaz et al., 2005, (Table 2).

Alumina, $\mathrm{MgO}$, LOI, and $\mathrm{Fe}_{2} \mathrm{O}_{3}$ concentrations of the claystone appear to be slightly below the range of the analyses by AlQazaz et al., 2005, while the silica concentrations, $\mathrm{CaO}, \mathrm{K}_{2} \mathrm{O}$, and $\mathrm{Na}_{2} \mathrm{O}$ are slightly higher than the limits of Al-Qazaz et al., 2005.
The presence of quartz in the claystone of the Injana Formation (Late Miocene) contributes to affecting the weight due to its low specific gravity. (Al-Bassam, 2004). In the study area, the amount of quartz is high and appears to be effective. At high temperature, quartz reacts with $\mathrm{Al}_{2} \mathrm{O}_{3}$ and $\mathrm{CaO}$ forming $\mathrm{Al}, \mathrm{Ca}$, and silicates; in this case, the free $\mathrm{CaO}$ that causes cracking of the bricks will be reduced (Awadh \& Abdullah, 2009). The claystone appears to have a slightly higher content of $\mathrm{CaO}$, which suggests that the calcite and clay minerals are the source of the $\mathrm{Ca}$. The carbonate content in claystone is a very important factor in forming bricks and must not exceed $40 \%$ (Al-Qazaz et al., 2005). If the amount of carbonate is in excess of $40 \%$, the bricks will swell due to the effect of carbon dioxide. LOI $\left(\mathrm{CO}_{2}\right.$ and $\left.\mathrm{H}_{2} \mathrm{O}\right)$ appears below the limits than the limits of Al-Qazaz et al., 2005, attributable to the presence of substantial volatiles originating from the clay minerals (mainly hydrous species) and decomposition of carbonates (Mezencevova et al., 2012). The amount of alkalis $\left(\mathrm{K}_{2} \mathrm{O}\right.$ and $\mathrm{Na}_{2} \mathrm{O}$ ) that act as flux materials was slightly higher due to the relatively high content of illite (Monterio \& Vieira, 2004). The chemical analyses of samples of claystone are within acceptable limits published by Al-Qazaz et al., 2005. As a result, shown in Table 2, the claystone is favorable for the brick industry.

\subsection{Mineralogy of claystone}

The XRD analysis provides information about the mineralogical composition. The XRD analyses show that the samples chosen from the Injana Formation consist of the non-clay and clay minerals. The average percentage of non-clay minerals, i.e., quartz is $36.4 \%$, calcite is $32.8 \%$, feldspar is $2.6 \%$, gypsum is $1.3 \%$, and dolomite is $0.7 \%$. The average percentage of the clay minerals can be described as kaolinite (10.5\%), illite (7.7\%), chlorite $(6.7 \%)$, and palygorskite $(6.0 \%)$ (Figure $3 \mathrm{~A}$ and B). 


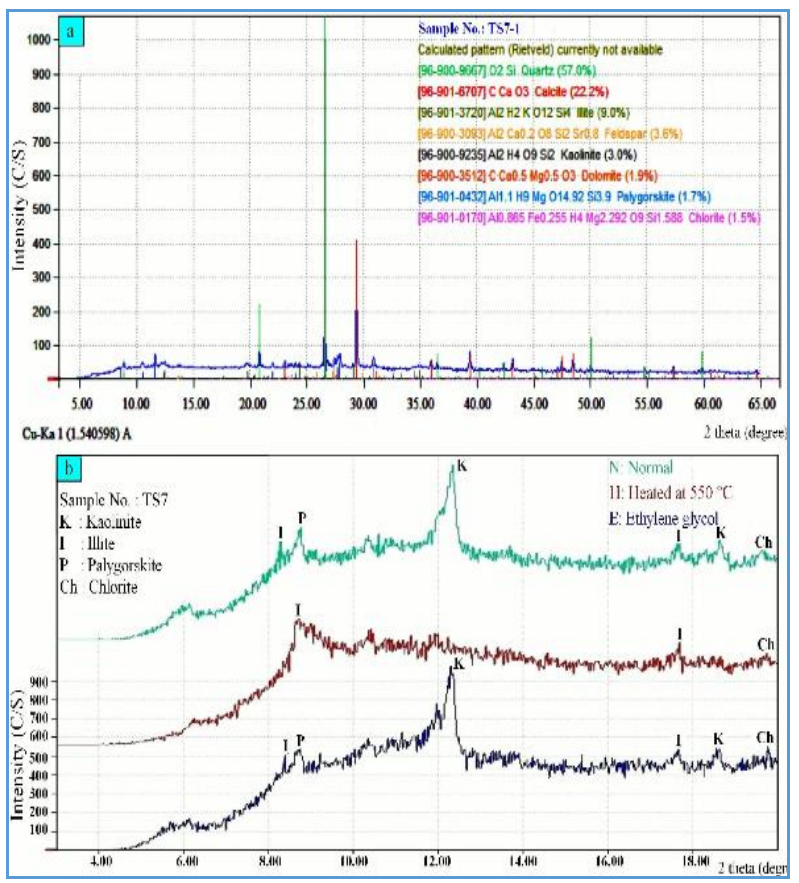

Fig. 3. XRD diffractograms of claystone sample TS7-1; A) Bulk sample, B) oriented clay fraction in different treatment stages.

\subsection{Physical characteristics of claystone}

\subsection{Grain-size distribution}

The grain size distribution is presented in Table 3. In the present study, the percentages of clay and silt were calculated by using the hydrometer test method while the percentages of sand by a wet sieving method (ASTM D422-63 2007). The silt fraction ranges from $37.1 \%$ to $54.8 \%$, followed by clay $(29.0 \%$ to $39.1 \%$ ), and sand (14.1\% to $26.8 \%$ ). Thus, the grain size falls within the parameters recognized for industrial-grade clay.

\subsubsection{Plasticity of claystone}

Plasticity is one of the most important factors for manufacturing claystone products. The clay plasticity is based on the Atterberg limits method that includes liquid limit (LL), plastic limit (PL), and plasticity index (PI). The LL and PL tests were performed using the Casagrande apparatus using the method described by Casagrande (1947). The PI represents the size of the range of water content where the clay shows plastic properties and exhibits the difference between the LL and the PL (Punmia et al., 2003). The claystone samples have LL range from $42.2 \%$ to $56.2 \%$ with an average of $49.0 \%$, PL varies from $20 \%$ to $29.3 \%$ with an average of $24.5 \%$. Accordingly, the PI of the claystone of Injana varies from $20.1 \%$ to $29.84 \%$.

According to the ASTM for liquid limit, plastic limit, and PI D 4318-05 (2005) and the modified Casagrande plasticity diagram (Keystone, 2003), Figure 4 shows that the samples (TS1-1, TS2-1, TS5-1, TS6-1, TN2-2, and TN6-1) are of low plasticity index (CL). On the other hand, the samples (TS3-1, TS4-1, TS7-1, TH7-1, TN3-2, and TN5-2) are of high plasticity index $(\mathrm{CH})$. Bain, 1974, stated that the plasticity of clay depends on the PI, which varies from $20.12 \%$ to $29.84 \%$, with an average of $24.3 \%$. The average of PL is $24.5 \%$, and the average of LL is $49.0 \%$ (Table 4). These values meet the standard Iraqi (ISS, 1993), for brick manufacturing. 
Table 2. Geochemical analysis results (\%) of claystone samples in the study area.

\begin{tabular}{|c|c|c|c|c|c|c|c|c|c|c|c|c|c|}
\hline $\begin{array}{l}\text { Sample } \\
\text { No. } \\
\end{array}$ & $\mathrm{SiO}_{2}$ & $\mathrm{Al}_{2} \mathrm{O}_{3}$ & $\mathrm{Fe}_{2} \mathrm{O}_{3}$ & $\mathrm{CaO}$ & MgO & $\mathrm{K}_{2} \mathrm{O}$ & $\mathrm{Na}_{2} \mathrm{O}$ & $\mathrm{TiO}_{2}$ & MnO & LOI & $\mathrm{SO}_{3}$ & $\mathrm{Cl}$ & Total \\
\hline \multicolumn{14}{|c|}{$\%$} \\
\hline TN1-1 & 41.1 & 9.1 & 6 & 13.6 & 5.4 & 2 & 0.8 & 0.67 & 0.13 & 20.2 & 0.1 & 0.5 & 99.7 \\
\hline TN1-2 & 48.6 & 10.4 & 5.7 & 12.1 & 5.5 & 2.2 & 0.5 & 0.59 & 0.14 & 12.2 & 0.2 & - & 98 \\
\hline TN2-1 & 42.4 & 10.7 & 5.9 & 15.6 & 5.2 & 1.3 & 1.9 & 0.75 & 0.1 & 14.9 & 0.4 & - & 99.1 \\
\hline TN2-2 & 34.7 & 7.7 & 5.5 & 18.9 & 4.4 & 1.1 & 1.8 & 0.77 & 0.1 & 22.8 & 1 & 0.8 & 99.6 \\
\hline TN3-1 & 35.4 & 7.4 & 4.1 & 27.6 & 4.1 & 1.4 & 1.6 & 0.66 & 0.1 & 16.5 & 0.3 & 0.6 & 99.6 \\
\hline TN3-2 & 37.6 & 9.1 & 6.6 & 18.5 & 5.3 & 1.4 & 1.8 & 0.87 & 0.11 & 17.4 & 0.3 & 0.7 & 99.6 \\
\hline TN4-1 & 36.2 & 8 & 5.4 & 21.7 & 4.9 & 1.2 & 2.4 & 0.84 & 0.1 & 17.4 & 0.7 & 0.9 & 99.6 \\
\hline TN4-2 & 40.6 & 9.2 & 4.8 & 19.3 & 4.4 & 1.2 & 2 & 0.74 & 0.1 & 16.9 & 0.7 & - & 99.9 \\
\hline TN5-1 & 40.8 & 9 & 5.2 & 21.8 & 4.9 & 1.7 & 1.7 & 0.82 & 0.08 & 12.5 & 0.6 & 0.5 & 99.6 \\
\hline TN5-2 & 42.2 & 9.1 & 5.4 & 14.3 & 5 & 1.9 & 3.7 & 0.83 & 0.07 & 14.7 & 0.2 & 2.3 & 99.6 \\
\hline TN6-1 & 40.5 & 9.1 & 5.8 & 15.2 & 5 & 1.5 & 1.8 & 0.85 & 0.09 & 18 & 1 & 0.8 & 99.6 \\
\hline TN6-2 & 40.4 & 9.1 & 6 & 16.9 & 6.2 & 2.1 & 1.5 & 0.72 & 0.05 & 15.8 & 0.3 & 0.7 & 99.7 \\
\hline TS1-1 & 40.6 & 10.2 & 5.5 & 16.3 & 5.6 & 1.5 & 1.7 & 0.66 & 0.1 & 16.3 & 0.3 & - & 98.8 \\
\hline TS1-2 & 38.6 & 9 & 6.2 & 19.7 & 6.3 & 2.1 & 1.8 & 0.74 & 0.08 & 14.3 & 0.2 & 0.7 & 99.7 \\
\hline TS2-1 & 46.6 & 11.2 & 7.8 & 10.5 & 6.7 & 2.4 & 1.2 & 0.91 & 0.13 & 11.2 & 0.5 & 0.5 & 99.6 \\
\hline TS2-2 & 37.5 & 8.8 & 6.2 & 18.3 & 6.1 & 2 & 1.6 & 0.83 & 0.09 & 17.4 & 0.2 & 0.7 & 99.7 \\
\hline TS3-1 & 37.1 & 8.8 & 6.1 & 18 & 5.2 & 1.4 & 2.1 & 0.83 & 0.1 & 16.6 & 1.2 & 0.5 & 98 \\
\hline TS3-2 & 47.5 & 11.1 & 5.8 & 13.1 & 4.8 & 1.8 & 1.6 & 0.77 & 0.1 & 13.2 & 0.2 & - & 99.97 \\
\hline TS4-1 & 37.6 & 9.1 & 6.6 & 18.6 & 4.8 & 1.4 & 1.5 & 0.9 & 0.11 & 17.9 & 0.3 & 0.6 & 99.6 \\
\hline TS4-2 & 47.2 & 9.1 & 4.6 & 15.9 & 3.8 & 1.5 & 1.5 & 0.61 & 0.08 & 15.1 & 0.3 & - & 99.6 \\
\hline TS5-1 & 36.8 & 8.8 & 6.7 & 17.3 & 5.4 & 1.6 & 1.3 & 0.8 & 0.11 & 19.6 & 0.6 & 0.6 & 99.6 \\
\hline TS5-2 & 41.9 & 8.8 & 4.2 & 15.8 & 3.1 & 1.6 & 1 & 0.76 & 0.07 & 22.1 & 0.2 & 0.4 & 99.7 \\
\hline TS6-1 & 33.3 & 8.1 & 5.8 & 26.6 & 4.8 & 1.2 & 1.9 & 0.75 & 0.1 & 15.9 & 0.5 & 0.7 & 99.6 \\
\hline TS6-2 & 42.8 & 10.5 & 5.7 & 15.6 & 5.4 & 1.4 & 1.9 & 0.71 & 0.1 & 15.3 & 0.6 & - & 100 \\
\hline TS7-1 & 38.1 & 8.6 & 5.8 & 19.9 & 5.2 & 1.4 & 1.9 & 0.84 & 0.09 & 15.7 & 1.2 & 0.8 & 99.5 \\
\hline TS7-2 & 42.5 & 9.3 & 4.9 & 15.9 & 5.2 & 1.5 & 1.8 & 0.63 & 0.08 & 16.4 & 1.4 & - & 99.4 \\
\hline TH10-1 & 45.2 & 7.8 & 4.6 & 8.6 & 7.9 & 1.6 & 2.6 & 0.72 & 0.07 & 17.4 & 2.1 & 1.1 & 99.7 \\
\hline TH9-1 & 53.1 & 11 & 6.2 & 8.9 & 6.1 & 2.5 & 1.3 & 0.98 & 0.06 & 8.9 & 0.3 & 0.2 & 99.6 \\
\hline TH7-1 & 43.1 & 9.1 & 4.7 & 16 & 5.2 & 1.6 & 1.7 & 0.64 & 0.09 & 17.1 & 0.7 & - & 99.99 \\
\hline TH1-1 & 35.2 & 7 & 5.6 & 22.6 & 4 & 1.3 & 1.7 & 0.77 & 0.11 & 14 & 0.5 & 1.4 & 94.1 \\
\hline TH1-2 & 36.7 & 8.9 & 4.2 & 18 & 5.2 & 1.4 & 2.1 & 0.83 & 0.1 & 19.6 & 1.2 & 0.8 & 99.03 \\
\hline TH-1 & 52.9 & 7.5 & 6.2 & 13.4 & 6.2 & 2.6 & 0.6 & 0.7 & 0.08 & 6.9 & 2.2 & 0.5 & 99.78 \\
\hline TH-2 & 35.9 & 10.6 & 4.4 & 18.6 & 4.8 & 1.4 & 1.5 & 0.9 & 0.11 & 19.9 & 0.3 & 0.9 & 99.31 \\
\hline MAX & 53.1 & 11.2 & 7.8 & 27.6 & 7.9 & 2.5 & 3.7 & 0.98 & 0.14 & 22.8 & 2.1 & 2.3 & 100 \\
\hline MIN & 33.3 & 7 & 4.1 & 8.6 & 3.1 & 1.1 & 0.5 & 0.59 & 0.05 & 8.9 & 0.1 & 0.2 & 98 \\
\hline AV. & 40.9 & 9.1 & 5.6 & 17.1 & 5.2 & 1.6 & 1.7 & 0.77 & 0.09 & 16.1 & 0.6 & 0.7 & 99.5 \\
\hline *Q. AV. & 40.4 & 10.3 & 6.08 & 17.08 & 6 & 1.2 & 1.5 & & & 17 & & & \\
\hline
\end{tabular}

* Al-Qazaz et al., 2005. 
Table 3. Results of the grain size analysis.

\begin{tabular}{|c|c|c|c||}
\hline $\begin{array}{c}\text { Sample } \\
\text { No. }\end{array}$ & $\begin{array}{c}\text { Clay } \\
(\boldsymbol{\%})\end{array}$ & $\begin{array}{c}\text { Silt } \\
(\boldsymbol{\%})\end{array}$ & $\begin{array}{c}\text { Sand } \\
(\boldsymbol{\%})\end{array}$ \\
\hline TS1-1 & 35 & 50.9 & 14.1 \\
TS2-1 & 39 & 44.5 & 16.5 \\
TS3-1 & 33 & 43.8 & 23.2 \\
TS4-1 & 39.1 & 37.1 & 23.8 \\
TS5-1 & 35 & 41.5 & 23.5 \\
TS6-1 & 34 & 41.3 & 24.7 \\
TS7-1 & 29.1 & 49.3 & 21.6 \\
TN2-2 & 38 & 44.5 & 17.5 \\
TN3-2 & 32 & 41.2 & 26.8 \\
TN5-2 & 29 & 54.8 & 16.2 \\
TN6-1 & 32.5 & 50 & 17.5 \\
TH7-1 & 36 & 49.2 & 14.8 \\
Av. & 34.3 & 45.7 & 20 \\
Min. & 29.0 & 37.1 & 14.1 \\
Max. & 39.1 & 54.8 & 26.8 \\
\hline \hline
\end{tabular}

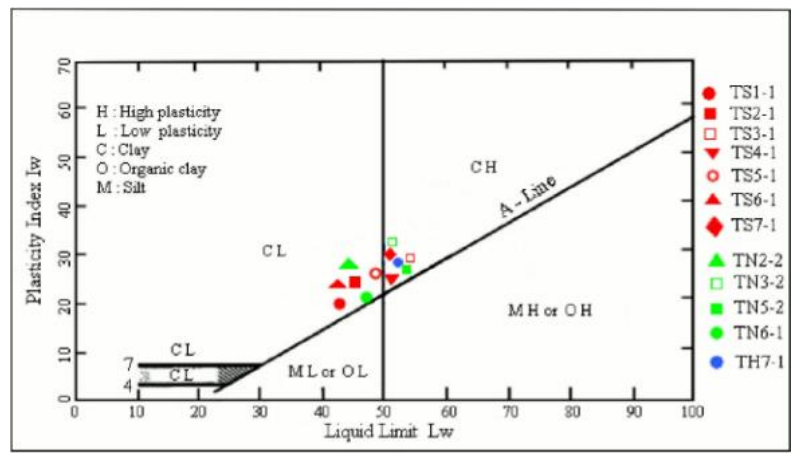

Fig. 4. The plasticity diagram shows the results of plasticity limits for claystone samples.
Table 4. Plasticity Limit values indicated by Casagrande test methods.

\begin{tabular}{||l|c|c|c||}
\hline \multirow{2}{*}{ Sample } & \multicolumn{3}{|c||}{ Plasticity Limit } \\
\cline { 2 - 4 } No. & $\begin{array}{c}\text { Liquid } \\
\text { Limit }\end{array}$ & $\begin{array}{c}\text { Plastic } \\
\text { Limit }\end{array}$ & $\begin{array}{c}\text { Plasticity } \\
\text { Index }\end{array}$ \\
\cline { 2 - 4 } & \multicolumn{3}{|c||}{$\mathbf{( \% )}$} \\
\hline TS1-1 & 43.7 & 21.74 & 21.96 \\
TS2-1 & 46.28 & 23.62 & 22.66 \\
TS3-1 & 56.16 & 27.2 & 28.96 \\
TS4-1 & 50.66 & 21.25 & 29.41 \\
TS5-1 & 49.05 & 26.75 & 22.3 \\
TS6-1 & 42.24 & 21.33 & 20.19 \\
TS7-1 & 50.58 & 25.5 & 25.08 \\
TN2-2 & 44.51 & 20 & 22.51 \\
TN3-2 & 53.04 & 23.2 & 29.84 \\
TN5-2 & 52.25 & 29.25 & 23 \\
TN6-1 & 47.26 & 27.14 & 20.12 \\
TH7-1 & 52.5 & 26.53 & 25.97 \\
Min. & 42.24 & 20 & 20.12 \\
AV. & 49 & 24.5 & 24.3 \\
Max. & 56.16 & 29.25 & 29.84 \\
\hline \hline
\end{tabular}

\subsubsection{Water Absorption capacity}

The WA test is performed on a brick to determine the amount of moisture content absorbed by brick (Figure 5). The WA is determined by using Iraqi standard specification No.25, 1993, (ISS No. 25, 1993). It can be obtained from the following simple equation.

$$
W=\frac{W 2-W 1}{W 2} * 100
$$

Where $\mathrm{W}$ is the water absorption, $\mathrm{W} 2$ is the weight of brick after 24 hours in the water, and $\mathrm{W} 1$ is the dry brick weight.

The WA is an important factor in the clay bricks used in construction (Sonbul and Abu Seif1, 2019). The bricks characterized by low absorption need little quantity of cement bonds, but those of high absorption need more cement so that the cost will be high (Al-Beyate, 2011). The studied samples' values range from $19.3 \%$ to $27.6 \%$, with an average of $23.2 \%$ (Table 5). The ISS No. 25 (1993) limited the acceptable WA (\%) ranges to be from 22 to 28 . 


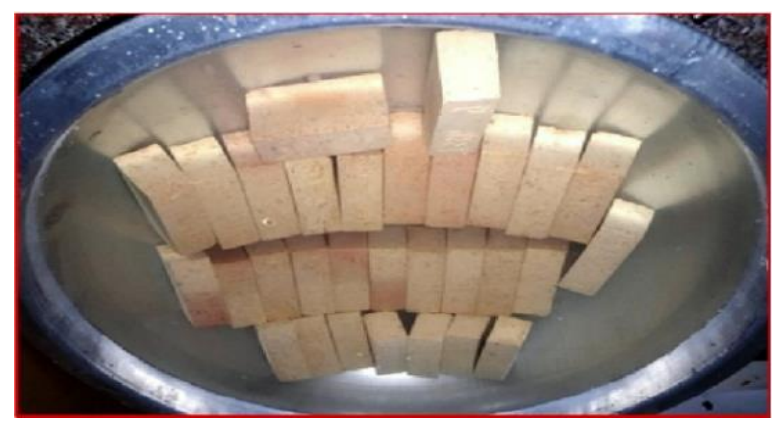

Fig. 5. Brick samples immerse in water during the water absorption test.

\subsubsection{Efflorescence}

Ef is defined as the residual salts on the brick surface after evaporating the water. According to the Australian Standards Relevant to Masonry, crystalline salts or amorphous crystals represent minor salts (ASRM, 2017).

The accepted value for brick manufacturing (class A) is $22 \%$ and $26 \%$ for class B. Thus, samples TS2-1, TS4 -1, TN5 2 , and TN6-1 are classified as class A; the rest are class $\mathrm{B}$ (Table 5). All samples are accordingly suitable for the brick industry. The Ef content ranged from nil to low, indicating the potential for use in the brick industry (Figure 6).

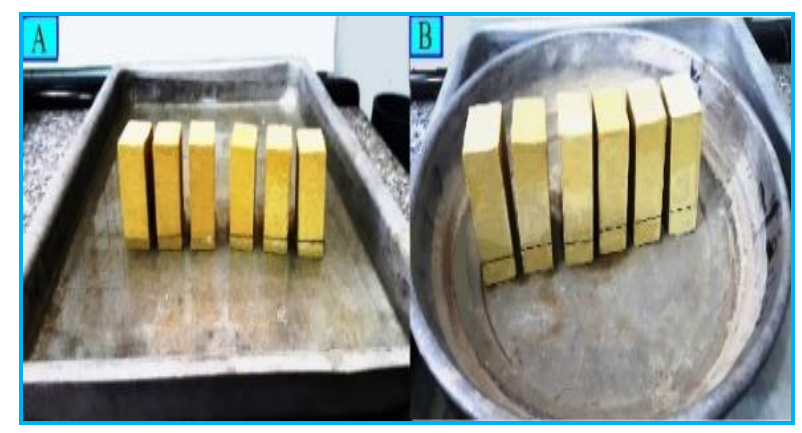

Fig. 6. Efflorescence test for some brick samples A-during immersed in water, Bafter dried from water.

Table 5. Results of engineering and physical properties of Injana claystone.

\begin{tabular}{|c|c|c|c|c|c|c|c|c|c|}
\hline \multirow{2}{*}{$\begin{array}{l}\text { Sample } \\
\text { No. }\end{array}$} & \multicolumn{3}{|c|}{$\begin{array}{c}\text { Brick } \\
\text { dimensions } \\
(\mathbf{c m})\end{array}$} & \multirow{2}{*}{$\begin{array}{l}\text { DL } \\
(\%)\end{array}$} & \multirow{2}{*}{$\begin{array}{l}\text { DV } \\
(\%)\end{array}$} & \multicolumn{4}{|c|}{ Physical characters } \\
\hline & $\mathbf{L}$ & $\mathbf{W}$ & $\mathbf{H}$ & & & $\begin{array}{c}\mathrm{CS} \\
\left(\mathrm{Kg} / \mathrm{cm}^{2}\right)\end{array}$ & $\begin{array}{l}\text { WA } \\
(\%)\end{array}$ & Ef & Class \\
\hline TS1-1 & 6.85 & 3.7 & 2.4 & 0.05 & 0.5 & 104 & 26.1 & Low & B \\
\hline TS2-1 & 6.9 & 3.7 & 2.4 & 0.1 & 0.9 & 204 & 20.2 & Nil & A \\
\hline TS3-1 & 6.87 & 3.7 & 2.4 & 0.07 & 0.7 & 113 & 25.9 & Low & $\mathrm{B}$ \\
\hline TS4-1 & 6.83 & 3.7 & 2.4 & 0.03 & 0.3 & 183 & 21.2 & Nil & A \\
\hline TS5-1 & 6.87 & 3.7 & 2.4 & 0.07 & 0.7 & 150 & 24.6 & Low & $\mathrm{B}$ \\
\hline TS6-1 & 6.88 & 3.7 & 2.4 & 0.08 & 0.8 & 167 & 21.1 & Low & B \\
\hline TS7-1 & 6.91 & 3.7 & 2.4 & 0.02 & 0.1 & 123 & 23.7 & Low & B \\
\hline TN2-2 & 6.89 & 3.7 & 2.4 & 0.01 & 0 & 165 & 26.2 & Low & B \\
\hline TN3-2 & 6.86 & 3.7 & 2.4 & 0.06 & 0.7 & 118 & 25.6 & Low & B \\
\hline TN5-2 & 6.86 & 3.7 & 2.4 & 0.06 & 0.7 & 225 & 19.3 & Nil & B \\
\hline TN6-1 & 6.88 & 3.7 & 2.4 & 0.08 & 0.8 & 181 & 21.8 & Nil & A \\
\hline TH7-1 & 6.85 & 3.7 & 2.4 & 0.05 & 0.5 & 127 & 22.9 & Low & B \\
\hline Average & 6.87 & 3.7 & 2.4 & 0.06 & 0.56 & 155 & 23.2 & Low & B \\
\hline
\end{tabular}




\subsubsection{Dimensional changes}

Linear shrinkage is determined by measuring the length of the sample before and after drying or firing. At high temperatures, the brick particles merged, leading to better proximity and a more enhanced linear shrinkage (Nkalih et al., 2018).

The burning bricks must have linear shrinkage $<8 \%$ in order to maintain good mechanical performance (Rguibi, 2017). High linear shrinkage leads to tension and breakage, resulting in reduced mechanical strength. Furthermore, the linear shrinkage and mechanical strength are negatively correlated. Linear strength (before and after drying) is calculated as follows:

Linear drying shrinkage $\%=\frac{L v-L d}{L v} * 100$

Where $\mathrm{Lv}$ is the length of the viscous sample $(\mathrm{cm})$ and Ld is the length of the dried sample $(\mathrm{cm})$.

The longitudinal deflation ranges from $0.01 \%$ to $0.1 \%$ with an average of $0.06 \%$, whereas volume deflation ranges from $0.1 \%$ to $0.9 \%$ with an average of $0.56 \%$ (Table 5). The produced bricks are characterized by smooth surfaces with parallel sharp and straight edges. It has a good general appearance that is free from cracks, and the color ranges from yellow to yellowish-white (Figure 7).

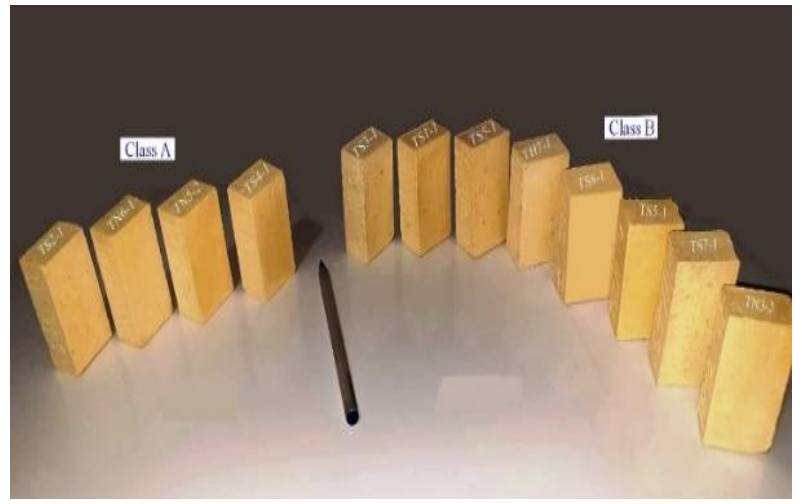

Fig. 7. Claystone brick samples belonging to categories $\mathrm{A}$ and $\mathrm{B}$.

\subsubsection{Compressive strength}

The CS test is higher than the standard of the ISS No. 25 (1993) and ranges from 104 to $225 \mathrm{~kg} / \mathrm{cm}^{2}$ with an average of $155 \mathrm{~kg} / \mathrm{cm}^{2}$ (Table 5). The decrease in porosity leads to increased density, compressive strength, and claystone samples' mechanical strength (Baccoura et al., 2008). The $160 \mathrm{Kg} / \mathrm{cm}^{2}$ and $110 \mathrm{Kg} / \mathrm{cm}^{2}$ are recommended as a minimum $\mathrm{CS}$ for class $\mathrm{A}$ and class $\mathrm{B}$, respectively, for the manufacturing bricks based on the ISS No. 25 (1993). Brick samples are cracking at a peak load range of 55.2 to $25.6 \mathrm{KN} / \mathrm{m}^{2}$ for example; the sample TS1-1 is cracking at $25.6 \mathrm{KN} / \mathrm{m}^{2}$ (Figure 8 ).

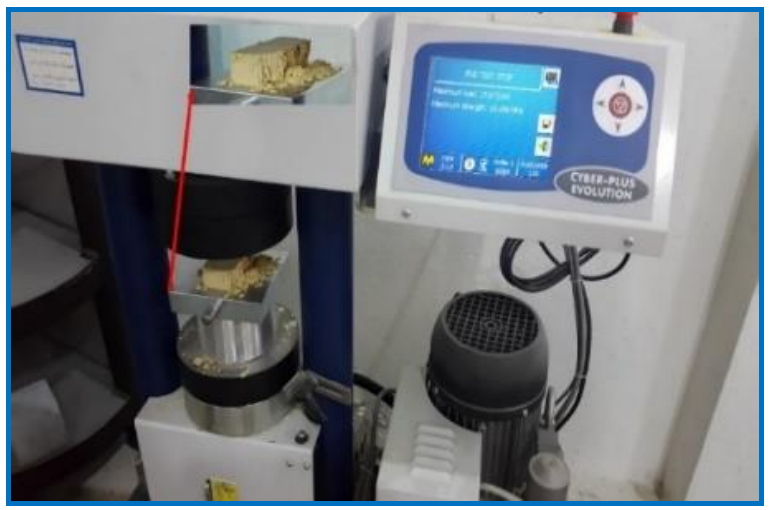

Fig. 8. Brick sample (TS1-1) in the compression machine shows cracking at $25.6 \mathrm{KN} / \mathrm{m}^{2}$ of the peak load.

\subsubsection{Mineral phase transformation}

The XRD analysis of the powdered brick is fired at $950{ }^{\circ} \mathrm{C}$ and derived from sample TS7-1 (Figure 9). The sample (TS7-1) formed from the firing up to $950^{\circ} \mathrm{C}$ resulting in the formation of new phases such as diopside (62.9\%), quartz (18.4\%), wollastonite $(8.28 \%)$, akermanite $(7.6 \%)$, Anorthite (6.25\%), Nosean (4.9\%), gehlenite $(3.75 \%)$ and Lazurite $(3.15 \%)$. The normal clay brick includes the following ingredients: silica (sand) 50\%-60\%, alumina (clay) 20\%-30\%, lime 2\%-5\%, iron oxides 
$5 \%-6 \%$, not more than $7 \%$, and magnetite less than $1 \%$ by weight (Punmia et al., 2003). The disappearance of clay minerals can summarize the most important mineral changes since they do not tolerate the high temperatures due to a collapse of the crystalline structure and loss of crystalline water (Abd, 2000). Carbonate minerals are completely consumed, forming new mineral phases such as gehlenite, which is one of the melilite group minerals (Hibbard, 2002). The firing process causes the decomposition of carbonates, clay, and silicates and the formation of a melt phase rich in $\mathrm{Si}, \mathrm{Al}, \mathrm{Ca}$, and $\mathrm{K}$. The feldspar evolves into anorthite (Trindade et al., 2009). In the sample TS7-1, kaolinite is consumed at $550^{\circ} \mathrm{C}$. Quartz is present throughout the entire temperature range. Gehlenite appears at $900^{\circ} \mathrm{C}$. Diopside appears at $900^{\circ} \mathrm{C}$ to $1000^{\circ} \mathrm{C}$.

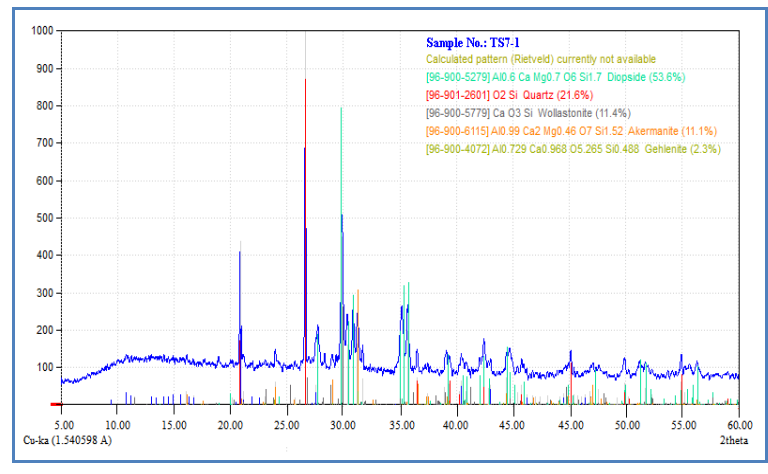

Fig. 9. XRD diffractograms of claystone (brick sample TS7-1) burned to $950^{\circ} \mathrm{C}$.

\section{Conclusions}

1. A proven reserve of the Late Miocene claystone of Injana Formation in the study area meets the Iraqi standards of brick manufacture and suitable to the brick industry.

2. The Late Miocene claystone collected from Injana Formation is composed of kaolinite $(10.5 \%)$, illite $(7.7 \%)$, chlorite
(6.7\%), palygorskite $(6.0 \%)$ and montmorillonite $(0.7 \%)$, quartz $(36.4 \%)$, calcite $(32.8 \%)$, feldspar $(2.6 \%)$, gypsum $(1.3 \%)$ and dolomite $(0.7 \%)$.

3. New mineral phases were formed after firing to $950{ }^{\circ} \mathrm{C}$ such diopside $(62.9 \%)$, quartz (18.4\%), wollastonite (8.28\%), akermanite (7.6\%), Anorthite (6.25\%), Nosean $(4.9 \%)$, gehlenite $(3.75 \%)$ and Lazurite $(3.15 \%)$.

4. The average of CS $\left(155 \mathrm{~kg} / \mathrm{cm}^{2}\right)$ for the burning claystone, the Atterberg limit values, and the WA (23.2\%) contribute towards the hypothesis that the claystones are suitable for the brick industry.

5. The results of dimensional changes revealed that the volumetric and linear shrinkage for brick samples is low during drying and firing at $950^{\circ} \mathrm{C}$.

6. The Ef is low, and thus salts are not a problem.

7. The grain size of the sample studied is composed of clay $(34.3 \%)$, silt $(45.7 \%)$, and sand (20\%).

8. The positive results confirm the possibility of Late Miocene claystone from the Injana Formation can be utilized as a raw material for brick production in the Najaf- Karbala plateau, Central Iraq.

\section{ACKNOWLEDGEMENTS}

The authors would like to thank the Adviser Office for Development Affairs at the Ministry of Industry and Minerals for approving the subject as a Ph.D. project.

\section{References}

Abd, S.H. (2000) Mineralogy and geochemistry study of sediments of AlNahrawan quarries and their effect in manufacturing of clay brick. MSc thesis (unpublished), University of Baghdad, 
College of Science, Department of Applied Geology, p.136.

Al-Bassam, K.S. (2004) Evaluation of the physical and chemical specifications of the raw materials used in making fired bricks. GEOSURV, Iraq. Report No. 2873. Internal report (Arabic). p 45.

Al-Beyate, H.F.A. (2011) Suitability of Injana Formation rocks for brick manufacturing in selected locations within Salah Al-Din Governorate. MSc thesis (unpublished), University of Tikrit, College of Science, Department of Geology, p.114.

Ali, M.H.; Hijab, B.R. and Al-Jahsar, S.H. (1990) Engineering geology. Dar Al-kutb for publication, Al-Mousel University (Arabic), p.576.

Al-Qazaz, D.; Boles, Q.M.; Jabori, W.M. and Noor Al-Dein. (2005) Reevaluation of the soil suitable for mud industry, Al-Sowera brick factory. The State Company of Geological Survey and Mining. Internal report (Arabic), p.18.

ASRM. (2017) Australian Standards Relevant to Masonry. Brick technical manual-BBP. Style. Version2, Sydney Australia, p.84.

ASTM D 4318-05. (2005) Standard Test Method for liquid limit, Plastic limit, and Plasticity Index of Soils. ASTM International, West Conshohocken, PA, USA.

ASTM D422-63 e2 (2007) Standard Test Method for Particle - Size Analysis of

Soils. ASTM International, West Conshohocken, PA, USA.

Awadh, S.M., and Abdullah, H.H. (2009) Mineralogical, geochemical, and geotechnical evaluation of Al-Sowera soil for the building brick industry in Iraq. Arabian Journal of Geosciences, 4:413-419.
Awadh, S.M. and Aboud, Z.S. (2013) Chemical and physical control processes on the development of caves in the Injana Formation, Central Iraq. Arabian Journal of Geosciences, 6:3765-3772.

Baccoura, H.; Medhioub, M.; Jamoussi, F.; Mhiri, T. and Daoud, A. (2008) Mineralogical evaluation and industrial applications of the Triassic clay deposits, Southern Tunisia. Materials Characterization Journal, 59:1613-1622.

Bain, J.A. (1974) Scientific Method in the Laboratory Assessment of Industrial Materials 1st Industrial Mineral Congress, London. P.240-253.

Buday. T. (1980) The Regional Geology of Iraq. Stratigraphy and Paleogeography. Publ. of GEOSURV, Baghdad, Vol. 1, 445P.

Casagrande, A. (1947) Plasticity chart for the classification of cohesive soils. Transactions of the American Society of Civil Engineers. P.783-811.

Dawood, R. M. (2000) Mineralogy, origin of celestite and the factors controlling its distribution in Tar Al- Najaf, Najaf Plateau. Msc. Thesis, Baghdad University. Iraq. P. 169.

Duggal, S.K. (2008) Building Materials. Third edition. New age international publishers, New Delhi. P. 525.

Grim, R.E. (1962) Clay mineralogy. International series in the earth planetary sciences. McGraw-Hill, London, P.422.

Hassan, K.M. (2007) Stratigraphy of Karbala - Najaf area, Central Iraq. Iraqi Bulletin of Geology and Mining, 3(2):53-62.

Hibbard, M.J. (2002) Mineralogy; a geologist point of view. Mc Graw AW com. (ed.) New York N.Y, p. 562.

Iraqi Standard Specification No. 25 for the year (1993) Clay Bricks (the other) 
Central apparatus for quality Inspections and control, Baghdad, Iraq. (In Arabic)

Ismail, N.R. and Omar, H.M. (2014) Assessment of some clay deposits from Fatha Formation (M. Miocene) for brick manufacturing in Koya area, NE Iraq. The Scientific Journal of Koya University, 2(1):16-22.

Keystone. (2003) Technical Information Sheets. Keystone Retaining Wall System. Silt/ Clay Soils- Atterberg Limits. P. 37.

https://sistemasdemurosdecontencion.com/d vd/index_html_files/Technical\%20Notes.pdf

Maala, K.; Sood, Q.; Khames, D.; Jabo, B.; Al-Saade, N. and Khadhum, M. (2007) Laboratory assessment for utilization of Neogene mudstones in manufacturing of building bricks. Iraqi Bulletin of Geology and Mining, 3(2):1-15.

Merza, T.A. and Mohyaadldin, M. (2005) Manufacture of brick tiles from local raw materials, N \& NE Iraq. Zankoy Sulaimani Journal, 8(1):31- 45.

Mezencevova, A.; Yeboah, N.N.; Burns, S.E.; Kahn, L.F., and Kurtis, K.E. (2012) Utilization of Savannah Harbor river sediment as the primary raw material in production of fired brick. Journal of Environmental Management, 8 (30):128136.

Monterio, S.N. and Vieira, C.M. (2004) Influence of firing temperature on the ceramic properties of clays from Campos dos Goytacazes, Brazil. Journal of Appl. Clay Sci., 27:229-234.

Nkalih, A.M.; Pilate, P.; Yongue, R.F.; Njoya, A. and Fagel, N. (2018) Suitability of Foumban Clays (West Cameroon) for Production of Bricks and Tiles. Journal of Minerals and Materials Characterization and Engineering, 6:244-256.
Punmia, B.C., Jain, A.K., and Jain, A.K. (2003) Comprehensive basic civil engineering. Laxmi Publications (P) Ltd., New Delhi. P. 441.

Rguibi, Y.E. (2017) Eco-friendly fired clay bricks, bachelor thesis, Al-akhawayn University, School of Science \& engineering. P. 58.

Šál, J. (2019) Testing of brick clay modifications as a raw material for building ceramic products. Published by EDP Sciences. MATEC Web of Conferences, 279:22-28.

Shamiah, M.J.; Madlaji, M.S. and Nassour, A.G. (2018) Recycling construction and demolition waste: A case study in the Euphrates Basin area in the eastern region of Syria. Kuwait Journal of Science. 45 (4) pp 59 - 65.

Sonbul, A.R. and Abu Seif1, E.S. (2019) Geotechnical performance of sandy bricks made with fine aggregates of sand dunes, Saudi Arabia. Arabian Journal of Geosciences, p.126-166.

Topolinski, S. (2019) Unconfined Compressive Strength Properties of a Cement- Organic Soil Composite. Published by IOP Publishing Ltd. Journal of Materials Science and Engineering, 471:1080-1088.

Trindade, M.; Dias, M.; Coroado, J., and Rocha, F. (2009) Mineralogical transformations of calcareous rich clays with firing: a comparative study between calcite and dolomite rich clays from Algarve, Portugal. Journal of Applied Clay Science, 42:345-355.

$\begin{array}{ll}\text { Submitted } & : 01 / 05 / 2019 \\ \text { Revised } & : 18 / 03 / 2020 \\ \text { Accepted } & : 24 / 03 / 2020 \\ \text { DOI } & : 10.48129 / \text { kjs.v48i2.9006 }\end{array}$


Evaluation of the Injana claystone from Central Iraq for the brick industry 